\title{
Action of Complement in Hereditary Angioneurotic Edema: The Role of C'1-Esterase *
}

\author{
Virginia H. Donaldson $\dagger$ and Fred S. Rosen $\ddagger$ \\ (From the Research Division, St. Vincent Charity Hospital, the Department of Medicine, \\ Western Reserve University School of Medicine, Cleveland, Ohio; and the \\ Department of Pediatrics, Harvard Medical School, and the Children's \\ Hospital Medical Center, Boston, Mass.)
}

The tendency to have severe attacks of localized angioneurotic edema may be inherited as an autosomal dominant trait (1-7). The hereditary form of angioneurotic edema is also distinguishable by a biochemical abnormality in that affected persons lack detectable serum inhibitor of an enzyme derived from the first component of complement (C'1-esterase) (8). This serum deficiency is detectable before the onset of symptoms, which may appear at any time from 1 year of age to adult life. Although serum inhibitor of $C^{\prime} 1$ esterase is constantly absent from sera of patients, attacks of edema are episodic and self-limited and affect only circumscribed areas of the body. The present studies were undertaken to define changes in $C^{\prime} 1$-esterase and the components of complement in serum of patients during attacks of edema and during asymptomatic intervals.

Affected members of a family reported earlier (9) had no inhibitor of C'1-esterase in their serum, whereas sera from unaffected relatives contained normal amounts. Affected persons also developed C'1-esterase activity in their serum, but relatives and other normal individuals did not. When patients were free of swelling, there was evidence that small amounts of $C^{\prime} 1$ in their serum had been converted to $C^{\prime} 1$-esterase. During attacks of superficial swelling, laryngeal edema, or abdominal pain, C'1-esterase activity was readily detectable in both serum and plasma.

* Submitted for publication March 30, 1964 ; accepted July 20, 1964.

Supported by grants from the Cleveland Area Heart Society, the National Institutes of Health (AI-0587701), and the John A. Hartford Foundation.

† Fellow of the Ohio State Heart Association and of the National Hemophilia Foundation.

¥ Career Development Award (1-K3-AM-19,650-01) from the U. S. Public Health Service, 1963.
Thus, symptoms of hereditary angioneurotic edema were associated with enhanced generation of C'1-esterase. Ratnoff and Lepow have demonstrated that $\mathrm{C}^{\prime} 1$-esterase can increase vascular permeability in the skin of the guinea pig and that purified serum inhibitor of $C^{\prime} 1$-esterase can impair this response (10). C'1-esterase may also serve to increase vascular permeability in hereditary angioneurotic edema.

\section{Methods}

Nomenclature. Complement activity resides in a group of proteins in fresh serum. Although required for immune hemolysis and immune cellular injury in vitro, its role in human physiology is unclear. Four major components of complement are designated by number, indicating chronological order of their discovery: $C^{\prime} 1, C^{\prime} 2$, $\mathrm{C}^{\prime} 3$, and $\mathrm{C}^{\prime} 4$ (11). A part of $\mathrm{C}^{\prime} 1$ exists as a proenzyme which, under appropriate conditions, is converted to an active enzyme called C'1-esterase (12-18).

Recent studies of Lepow and associates have shown that $C^{\prime} 1$ may be chromatographically resolved into three subcomponents, referred to as $C^{\prime} 1 \mathrm{q}, \mathrm{C}^{\prime} 1 \mathrm{r}$, and $\mathrm{C}^{\prime} 1 \mathrm{~s}$ (19). $\mathrm{C}^{\prime} 1 \mathrm{q}$ is an $11 \mathrm{~S}$ globulin, probably identical to the protein that Müller-Eberhard and Kunkel called $\mathrm{C}^{\prime} \mathrm{O}$ (20) and Taranta, Weiss, and Franklin (21) described as participating in immune hemolysis. $C^{\prime} 1 \mathrm{r}$ was not identifiable with previously described components of complement and was proposed as a new component (19). $\mathrm{C}^{\prime} 1 \mathrm{~s}$ was chromatographically and antigenically related to $\mathrm{C}^{\prime} 1$-esterase $(17-19,22)$.

Once activated, $\mathrm{C}^{\prime} 1$-esterase can readily inactivate the fourth $\left(C^{\prime} 4\right)$ and second $\left(C^{\prime} 2\right)$ components of complement and hydrolyze several synthetic amino acid esters, most notably $N$-acetyl-L-tyrosine ethyl ester (12-15). Normal human serum contains an $\alpha_{2}$ globulin that inhibits these actions of $C^{\prime} 1$-esterase stoichiometrically $(15,23-25)$. The action of this inhibitor was absent in hereditary angioneurotic edema (8).

Procedure. Serum was separated from clotted blood by centrifugation at $0^{\circ} \mathrm{C}$ within an hour of venipuncture and stored at $-60^{\circ}$ C. Plasma was obtained by using disodium ethylenediamine tetraacetate (EDTA) as an anticoagulant to provide a final plasma concentration of 
$1 \times 10^{-8} \mathrm{M}$. When necessary, serum and EDTA plasma samples were shipped by air in insulated packing cases with 30 pounds of dry ice. Immediately before the experimental procedures, these samples were thawed quickly at $37^{\circ} \mathrm{C}$ and then kept at 0 to $4^{\circ} \mathrm{C}$ until used. Matched serum and EDTA plasma samples were obtained from the same phlebotomy in some instances, and their esterolytic and complement inactivating properties were compared.

$\mathrm{C}^{\prime} 1$-esterase used in assays to measure the inhibitory properties of serum or plasma samples was prepared from a euglobulin fraction of human serum as described by Lepow, Ratnoff, Rosen, and Pillemer (12).

Hydrolysis of $N$-acetyl-L-tyrosine ethyl ester by C'1-esterase was measured with a microformol titration using $0.05 \mathrm{~N}$ sodium hydroxide to quantify acid liberated during incubations. One unit of $\mathrm{C}^{\prime} 1$-esterase is that amount which hydrolyzes $0.5 \mu$ mole of $N$-acetyl-L-tyrosine ethyl ester in a standard 15 -minute assay at $37^{\circ} \mathrm{C}$ (23). To measure $C^{\prime} 1$-esterase-like activity in an esterolytic assay, serum or plasma was substituted for $\mathrm{C}^{\prime} 1$ esterase in a standard assay mixture. When the volume of this mixture was increased, the quantity of each component was increased in proportion to its cuncentration in the standard assay. The $N$-acetyl-L-tyrosine ethyl ester monohydrate was prepared in the laboratories of the Department of Chemistry of Western Reserve University and was chromatographically pure. The nitrogen content of this compound was $5.04 \%$ by weight (97\% of theoretical value), and the melting point was $75.5^{\circ}$ to $79^{\circ} \mathrm{C}$. It was dissolved in 2-methoxyethanol ${ }^{1}$ in a concentration of $1.6 \mathrm{M}$. Final concentration of the ester in assay mixtures was $0.08 \mathrm{M}$. There was no spontaneous hydrolysis of this substrate during

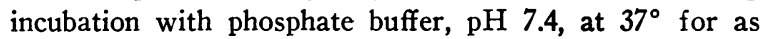
long as 3 hours. The assay procedure is sensitive to differences of 2 or more $U$ of esterase activity.

The inhibitory property of human serum that is directed against $C^{\prime} 1$-esterase will be referred to as serum inhibitor of $C^{\prime} 1$-esterase, even though the inhibitor was not fractionated from serum before assay. Highly purified human serum inhibitor of C'1-esterase was prepared as described by Pensky, Levy, and Lepow (24, 25 ). One unit of inhibitor is the amount which inhibits the action of $10 \mathrm{U}$ of $\mathrm{C}^{\prime} 1$-esterase (23).

The components of complement in serum were titrated by published methods using a hemolytic assay (26-29). Serum reagents to measure $C^{\prime} 1, C^{\prime} 2, C^{\prime} 3$, and $C^{\prime} 4$ are known as R1, R2, R3, and R4, respectively. These reagents were markedly deficient in the component in question and fulfilled requirements published earlier (26-29). In reading complement titrations, a $50 \%$ hemolytic end point was estimated, or hemolysis was measured directly by comparing optical densities of hemolysates at a wave length of $541 \mathrm{~m} \mu$ in a Beckman DU spectrophotometer. To measure $\mathrm{C}^{\prime} 3$ with sensitized erythrocytes that already contained $C^{\prime} 1, C^{\prime} 4$, and $C^{\prime} 2$

1 Methyl Cellosolve, Matheson Co., Norwood, Ohio. activities, the procedure described by Leon was followed (30).

Sodium phosphate buffer at an ionic strength of 0.15 and $\mathrm{pH}$ of 7.4 was used in assays to determine hydrolysis of $N$-acetyl-L-tyrosine ethyl ester; triethanolaminebuffered saline (TBS) at $\mathrm{pH} 7.4$, ionic strength 0.15 , containing $1.5 \times 10^{-4} \mathrm{M}$ calcium and $5 \times 10^{-4} \mathrm{M}$ magnesium ions, was employed as diluent in hemolytic assays to measure complement or components thereof. The preparation of this buffer has been described (31).

Subcomponents of $\mathrm{C}^{\prime} 1$ were differentiated by means of centrifugation in a preparatory ultracentrifuge, Spinco model L, using a linear density gradient of sucrose varied in concentration from $10 \%$ to $40 \%$. The technique for this separation was modified by Naff, Pensky, and Lepow (32) from the procedure described by Martin and Ames (33). Subcomponents of $C^{\prime} 1$ were measured in a hemolytic assay designed to measure one in the presence of adequate quantities of the other two, as detailed by Naff and associates (32).

To measure the effect of $C^{\prime} 1$-esterase upon $C^{\prime} 4$, normal pooled human serum that had been heated to $56^{\circ} \mathrm{C}$ for 30 minutes was used as a source of $C^{\prime} 4$ free of $C^{\prime} 1$ and $C^{\prime} 2$ (34). Sera from persons with hereditary angioneurotic edema, or fractions thereof, were incubated with this $\mathrm{C}^{\prime} 4$ at $0^{\circ} \mathrm{C}$ for 30 minutes, and the residual $\mathrm{C}^{\prime} 4$ was titrated in a hemolytic assay using serial dilutions of the incubation mixture and R4. This method of measuring $C^{\prime} 1$-esterase is much more sensitive than the esterolytic assay and about 100 times as sensitive as titration of residual $\mathrm{C}^{\prime} 2$, which is less readily inactivated by $\mathrm{C}^{\prime} 1$-esterase (34). The accuracy of the titration is limited by use of double dilutions, rendering a one-tube difference of questionable significance.

Immunoelectrophoresis of fresh human serum and "complement fixed" human serum was performed by the method of Grabar and Williams (35). To prepare complement fixed serum, precipitates of human gamma globulin complexed with rabbit antihuman gamma globulin were washed with cold saline and then incubated with fresh human serum at $37^{\circ} \mathrm{C}$ for 1 hour. The mixture was then centrifuged at $0^{\circ} \mathrm{C}$, and the precipitated aggregates were removed from the complement fixed serum. After electrophoresis, bands of precipitation were developed with two different rabbit antisera. Rabbit antiserum against human $C^{\prime} 4\left(\beta_{1 E}\right)$ was prepared by $\mathrm{Dr}$. H. J. Müller-Eberhard (36). Rabbit antiserum to both human $C^{\prime} 4\left(\beta_{1 \mathrm{IE}}\right)$ and to a portion of $C^{\prime} 3\left(\beta_{1 \mathrm{C}}\right)(37)$ was prepared by Dr. Franz Peetoom by injecting rabbits with ovalbumin-rabbit antiovalbumin precipitates that had been incubated in fresh human serum and then washed with cold saline (38).

\section{Results}

Sera obtained from affected members of a kindred with hereditary angioneurotic edema lacked detectable inhibitor of C'1-esterase (Figure 1). Experiments characterizing esterolytic activity of 


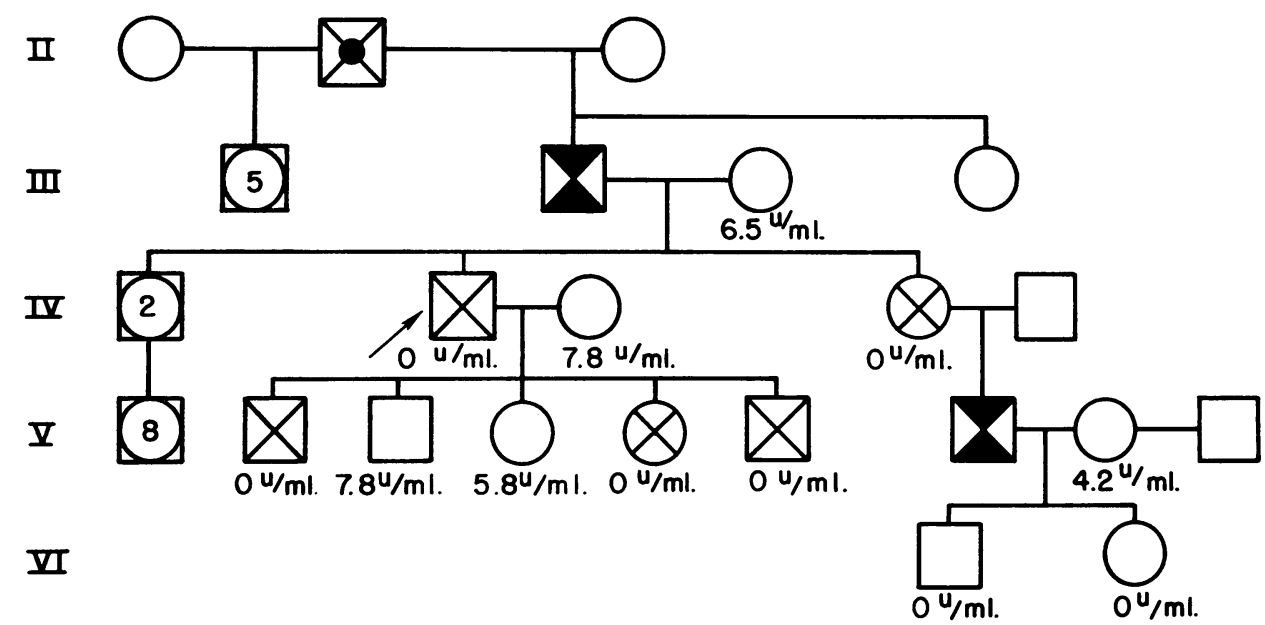

Fig. 1. LeVEls of Serum inhibitor of C'1 esterase in a Family (S) With hereditary ANGIONEURotic EDEMA. The units of inhibitor of $\mathrm{C}^{\prime} 1$-esterase per milliliter of serum from members of this kindred are enumerated beneath the characters representing those who could be tested. Generations are numbered according to the previous description of this pedigree, which was published by Heiner and Blitzer (9). Square characters designate males; circles represent females. Crossed characters denote those known to have attacks of hereditary angioneurotic edema; those with half of the crossed area in black were persons who are believed to have died during an attack of edema. A black circle within a character indicates death due to causes other than hereditary angioneurotic edema, so far as is known.

serum and plasma and components of complement in serum were performed on blood samples from members of generations IV and V (Figure 1).

A) C'1-esterase activity in blood of persons with hereditary angioneurotic edema. Since samples of serum and plasma obtained from individuals with hereditary angioneurotic edema lacked inhibitor of $C^{\prime} 1$-esterase, both were tested for $C^{\prime} 1$ esterase activity. Plasma obtained during an attack of abdominal pain rapidly hydrolyzed $N$ acetyl-L-tyrosine ethyl ester, a synthetic substrate of $C^{\prime} 1$-esterase (Figure 2). Samples obtained after pain had subsided digested this ester, but less readily (Figure 2). Enhanced generation of

TABLE I

Effect of purified human serum inhibitor of $C^{\prime} 1$-esterase upon $N$-acetyl-L-tyrosine ethyl esterase activity in serum of a patient with hereditary angioneurotic edema

\begin{tabular}{ccc}
\hline C'1-esterase source & $\begin{array}{c}\text { Inhibitor } \\
\text { added to } \\
\text { assay } \\
\text { mixture }\end{array}$ & $\begin{array}{c}\text { Residual } \\
\text { C'l-esterase }_{\text {in assay }} \\
\text { mixture }\end{array}$ \\
\hline Serum of patient having attack & $U$ & $U$ \\
Serum of patient having attack & 0.64 & 5.1 \\
Partially purified C'l-esterase & 0 & 0 \\
Partially purified C'l-esterase & 0.64 & 18.9 \\
\end{tabular}

esterase activity was demonstrated in serum and plasma obtained during ten separate attacks of edema. Plasma and serum samples from unaffected members of this family and from other normal individuals contained inhibitor of $\mathrm{C}^{\prime} 1$-esterase and lacked $N$-acetyl-L-tyrosine ethyl esterase activity.

To further identify the esterase activity, the effect of highly purified serum inhibitor of $C^{\prime} 1$ esterase upon the esterolytic properties of serum samples was tested. In the experiment shown in Table I, enough inhibitor was added to a patient's serum to block all the $N$-acetyl-L-tyrosine ethyl esterase activity present. As predicted, the esterase activity was completely blocked. When smaller quantities of inhibitor were used, less than the predicted amount of inhibition was obtained, probably because further activation of $C^{\prime} 1$-esterase in serum containing proesterase can occur during assay (8).

B) Serum complement in hereditary angioneurotic edema. Further evidence that the enzymatic activity present in these plasma samples was due to $C^{\prime} 1$-esterase was obtained by measuring the residual amounts of $C^{\prime} 4$ and $C^{\prime} 2$ in sera obtained simultaneously. These two components 
of complement are readily inactivated by small amounts of $\mathrm{C}^{\prime} 1$-esterase, and they were measured in assay systems designed to detect the component in question. Normal serum contained no $C^{\prime} 1$ esterase activity, and titers of $\mathrm{C}^{\prime} 4$ and $\mathrm{C}^{\prime} 2$ were in the ranges shown in Table II. Serum obtained from patients during attacks of abdominal pain, swelling of the hands, and glottic edema contained readily measurable $C^{\prime} 1$-esterase activity and no detectable $\mathrm{C}^{\prime} 4$ or $\mathrm{C}^{\prime} 2$ (Table II). When hand swelling had subsided, $C^{\prime} 1$ esterase was no longer detectable in a patient's serum, but $C^{\prime} 4$ and $C^{\prime} 2$ were decreased. Other patients also had diminished amounts of $C^{\prime} 4$ and $C^{\prime} 2$ in their serum when free of swelling (Table II), as if small amounts of $C^{\prime} 1$-esterase were generated in the blood even between attacks.

When immune hemolysis occurs, $C^{\prime} 3$ acts after the participation of the other three major components of complement. However, serum from persons with hereditary angioneurotic edema had normal amounts of $C^{\prime} 3$ (Table II). Some other serum samples containing $C^{\prime} 1$-esterase activity, but lacking hemolytic $C^{\prime} 1$, did not provide a satisfactory assay medium for detection of hemolytic $\mathrm{C}^{\prime} 3$ with a conventional $\mathrm{R} 3$ and a one-step assay procedure. Sensitized sheep erythrocytes were incubated with $C^{\prime} 1, C^{\prime} 4$, and $C^{\prime} 2$ before measurement of $\mathrm{C}^{\prime} 3$ in a two-step assay as described by Leon (30). When this procedure was used, similar amounts of $\mathrm{C}^{\prime} 3$ were measurable in serum obtained from patients during and between attacks.

Immunoelectrophoretic studies of patient's sera provided confirmatory evidence that $C^{\prime} 4$ was altered while $C^{\prime} 3$ was unaffected (Figure 3 ). Normal serum formed a single precipitin band in the $\beta_{1 \mathrm{E}}$ position, corresponding to $C^{\prime} 4$, upon reacting with anti- $\beta_{1 \mathrm{E}}$ serum. ${ }^{2}$ Complement-fixed serum provided three bands of precipitation in this position upon reacting with antiserum to $\beta_{1 \mathrm{E}}$ and $\beta_{\mathbf{1 c}}$ globulins, ${ }^{3}$ and a single band of reaction with anti- $\beta_{1 \mathrm{E}}$ serum. $^{2}$ Serum from a patient with hereditary angioneurotic edema during and between attacks gave two indistinct bands of reaction in the $\beta_{1 \mathrm{E}}$ position with the antiserum to both $\beta_{1 \mathrm{E}}$ and $\beta_{1 \mathrm{C}}$ globulin. Although not ap-

2 From Dr. H. J. Müller-Eberhard.

3 From Dr. Franz Peetoom.

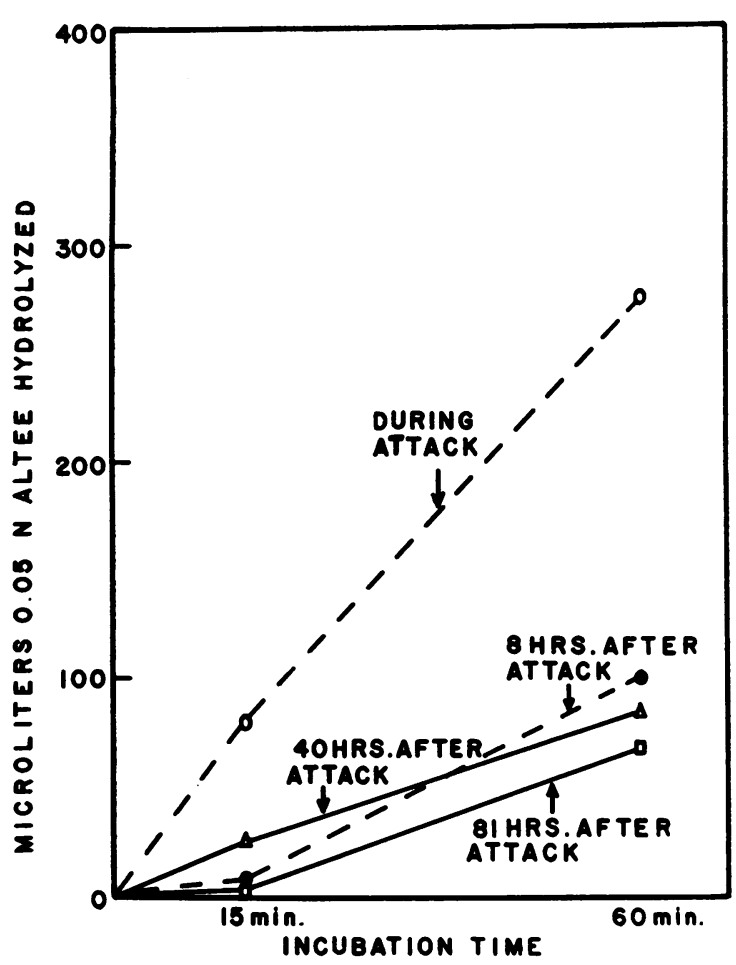

Fig. 2. C'1 eSterase aCtivity IN EDTA-plasma dURING AND AFTER ATTACK OF HEREDITARY ANGIONEUROTIC EDEMA. Samples of EDTA plasma obtained from a patient during an attack of hereditary angioneurotic edema were incubated with buffer and $N$-acetyl-L-tyrosine ethyl ester (ALTEE). After 15 and 60 minutes of incubation at $37^{\circ} \mathrm{C}, 1.0-\mathrm{ml}$ samples of the mixtures were pipetted into $1.0 \mathrm{ml}$ of neutral formaldehyde. Titratable acid in these mixtures was measured with a microformol titration using $0.05 \mathrm{~N} \mathrm{NaOH}$. Acid titrated at 15 and 60 minutes was compared to that in the original mixture before incubation.

Each curve represents C'1-esterase activity, as determined in this assay, which was found in plasma at the time denoted during and after an attack of severe abdominal pain. When pain subsided and the patient was able to be up and about, the attack was considered over.

parent in Figure 3, similar bands of reaction with anti- $\beta_{1 \mathrm{E}}$ serum were faintly visible in the $\beta_{1 \mathrm{E}}$ position before drying and staining the agar plates. Therefore, the $\beta_{1 \mathrm{E}}$ was apparently split into two or more components in complementfixed serum and hereditary angioneurotic edema serum. Both normal serum and serum from a patient exhibited normal precipitin bands in the $\beta_{10}$ position, corresponding to $C^{\prime} 3$, and contained normal amounts of hemolytic $C^{\prime} 3$. This contrasted with complement-fixed serum in which there was 

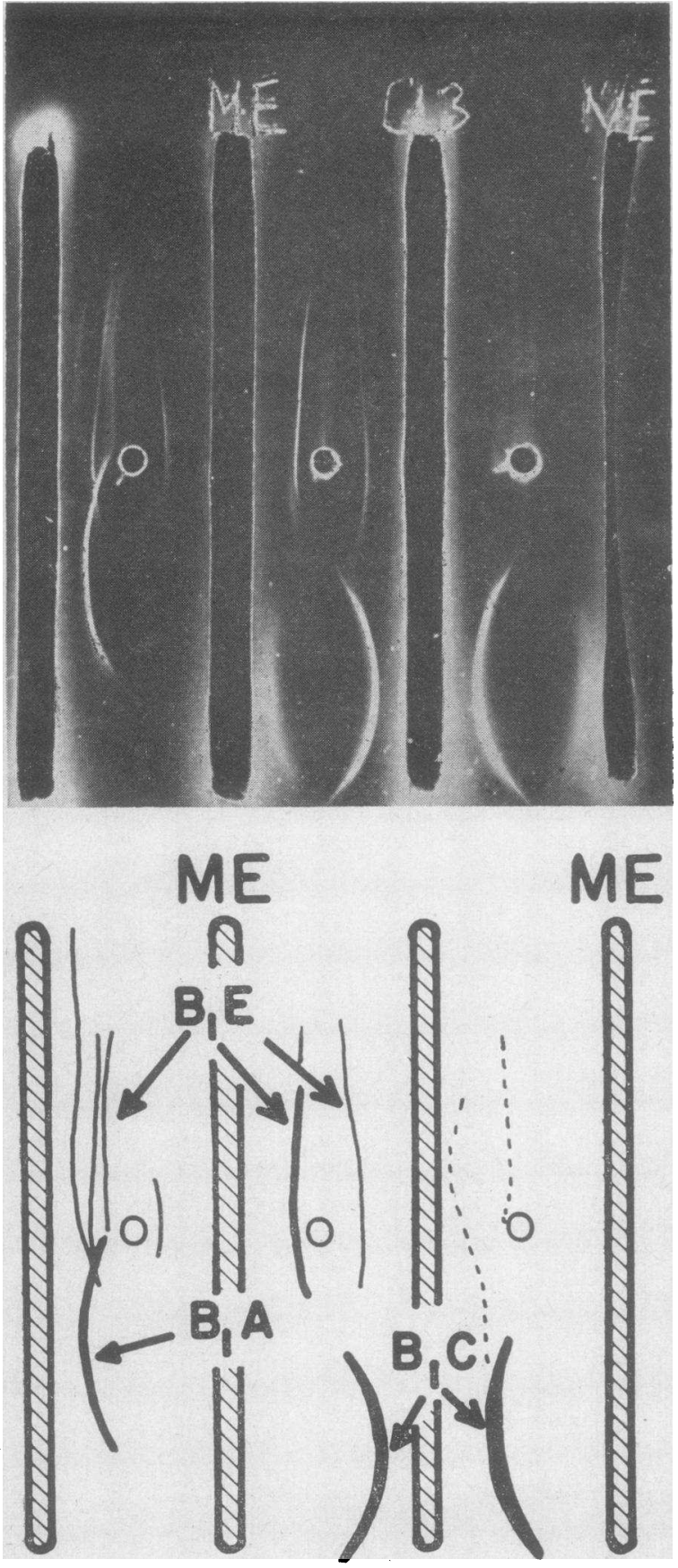

Fig. 3. IMMUNOELECtrophoretic PATterns OF $\mathrm{C}^{\prime} 3$ AND $C^{\prime} 4$ IN SERUM. The diagram illustrates the precipitin bands in the photograph. The center well contains normal serum, the right-hand well hereditary angioneurotic edema (HANE) serum, and the left-hand well, normal serum that had been incubated with human gamma globulin rabbit antihuman gamma globulin aggregates ("complement fixed"). The troughs marked $\mathrm{ME}$ contain an antiserum to the $\beta_{1 \mathrm{E}}$ globulin, and the a shift of this precipitin band from the $\beta_{1 \mathrm{C}}$ to the $\beta_{1 \mathrm{~A}}$ position (Figure 3 ).

When highly purified $\beta_{10}$ globulin (39) was injected into guinea pig skin, it did not increase vascular permeability.

C) Relative molecular weights of subcomponents of $C^{\prime} 1$ and of $C^{\prime} 1$-esterase in hereditary angioneurotic edema. Naff and associates have demonstrated the dissociation of $\mathrm{C}^{\prime} 1$ in the presence of EDTA into three subcomponents that can be separated in a sucrose density gradient upon ultracentrifugation (32). These subcomponents have sedimentation constants of $11 \mathrm{~S}$, $7 \mathrm{~S}$, and $4 \mathrm{~S}$ and are respectively designated $C^{\prime} 1 q, C^{\prime} 1 r$, and $C^{\prime} 1 s$ (19). When serum is ultracentrifuged in a density gradient, intact $\mathrm{C}^{\prime} 1$ and subcomponents thereof are all recovered from the bottom of the gradient, indicating that $C^{\prime} 1$ exists as a macromolecule in serum (32). It was of interest to determine whether the esterase activity in serum of a person with hereditary angioneurotic edema is associated with the macromolecular fraction in which $C^{\prime} 1$ is located in normal serum.

EDTA plasma and serum of a patient having an episode of swelling were ultracentrifuged in a sucrose density gradient. To identify C'1-esterase in fractions of the gradient mixture after centrifugation, the ability of these fractions to inactivate $C^{\prime} 4$ was tested. The serum and plasma used in this part of the experiment contained no measurable $C^{\prime} 1, C^{\prime} 4$, or $C^{\prime} 2$ and had $24 \mathrm{U}$ of $\mathrm{C}^{\prime} 1$-esterase per $\mathrm{ml}$.

In serum of patients, both $C^{\prime} 1 \mathrm{~s}$ and $C^{\prime} 1$-esterase were recovered from fractions at the bottom of the density gradient, which contained proteins of high molecular weight; in EDTA plasma of patients, both were found with lower molecular weight materials (4 S). Thus, $\mathrm{C}^{\prime} 1$-esterase and

other two troughs an antiserum to both $\beta_{10}$ and $\beta_{1 \mathrm{E}}$ globulins.

Normal serum gives normal $\beta_{1 \mathrm{E}}$ (upper) and $\beta_{1 \mathrm{C}}$ (lower) bands of precipitation. HANE serum forms a normal $\beta_{1 \mathrm{c}}$ band but no clear $\beta_{1 \mathrm{E}}$ band. In the complement fixed serum the $\beta_{1 \mathrm{c}}$ band is converted in toto to a $\beta_{1 \mathrm{~A}}$ band. With $\mathrm{ME}$ antiserum, the $\beta_{1 \mathrm{x}}$ band is altered in mobility and quantitatively diminished. With the other antiserum, two additional $\beta_{1 \mathrm{E}}$ bands are formed, presumed to be products of the enzymatic action of $C^{\prime} 1$ esterase upon $\mathrm{C}^{\prime} 4$. Faint traces of these two bands are seen in HANE serum. 
TABLE II

$C^{\prime} l$-Esterase activity in serum samples from persons with hereditary angioneurotic edema

\begin{tabular}{|c|c|c|c|c|c|c|}
\hline \multirow[b]{2}{*}{ Serum } & \multirow[b]{2}{*}{ Symptoms } & \multirow[b]{2}{*}{ C'1-Esterase } & \multicolumn{4}{|c|}{ Components of complement } \\
\hline & & & $C^{\prime} 1$ & $\mathrm{C}^{\prime} 2$ & $C^{\prime} 3$ & $C^{\prime} 4$ \\
\hline & & $U / m l$ serum & & $U / m l$ serum & & \\
\hline $\begin{array}{l}\text { Normal } \\
\text { Patient C.S. } \\
\text { Patient C.S. } \\
\text { Patient C.S. } \\
\text { Patient H.A.S. } \\
\text { Patient H.A.S. } \\
\text { Patient H.A.S. }\end{array}$ & $\begin{array}{l}\text { None } \\
\text { Abdominal pain } \\
\text { Hand swelling } \\
\text { Swelling of hand gone } \\
\text { None } \\
\text { None } \\
\text { Glottic edema }\end{array}$ & $\begin{array}{c}0 \\
13.2 \\
3.8 \\
0 \\
0 \\
0 \\
13.9\end{array}$ & $\begin{array}{c}1,280-2,560 \\
0 \\
320 \\
>1,280 \\
>1,280 \\
1,280 \\
<1,280\end{array}$ & $\begin{array}{c}240-280 \\
0 \\
0 \\
60 \\
<160 \\
160 \\
0\end{array}$ & $\begin{array}{c}280-360 \\
280 \\
320 \\
320 \\
320 \\
480 \\
320\end{array}$ & $\begin{array}{r}\geqslant 640 \\
0 \\
0 \\
40 \\
120 \\
160 \\
0\end{array}$ \\
\hline $\begin{array}{l}\text { Patient E.S. } \\
\text { Normal (simultaneous sample) }\end{array}$ & $\begin{array}{l}\text { None } \\
\text { None }\end{array}$ & $\begin{array}{l}0 \\
0\end{array}$ & $\begin{array}{l}1,280 \\
1,280\end{array}$ & $\begin{array}{l}180 \\
240\end{array}$ & $\begin{array}{l}360 \\
360\end{array}$ & $\begin{array}{r}80 \\
640\end{array}$ \\
\hline
\end{tabular}

$\mathrm{C}^{\prime} 1 \mathrm{~s}$ were localized in fractions containing $\mathrm{C}^{\prime} 1 \mathrm{~s}$ activity when normal serum and plasma were ultracentrifuged in this way. $\mathrm{C}^{\prime} 1 \mathrm{q}$ and $\mathrm{C}^{\prime} 1 \mathrm{r}$ activities were recovered from fractions of high molecular weight after ultracentrifugation of hereditary angioneurotic edema serum and normal serum. When plasma from a patient and a normal person were centrifuged in this manner, $\mathrm{C}^{\prime} 1 \mathrm{q}$ was in gradient fractions containing $11 \mathrm{~S}$ materials, and $C^{\prime} 1 \mathrm{r}$ in fractions containing $7 \mathrm{~S}$ materials in both instances.

D) Evidence for in vivo activation of C'1esterase in hereditary angioneurotic edema. It was possible that the $\mathrm{C}^{\prime} 1$-esterase activity in the blood of these individuals had all been generated after phlebotomy in vitro, and that free esterase activity did not actually exist in vivo. To establish the in vivo presence of $C^{\prime} 1$-esterase activity, blood was drawn from a normal individual and from a patient not having edema into a syringe containing enough purified inhibitor of $C^{\prime} 1$-esterase to provide a normal concentration of the material in the volume of blood obtained. The amount of $\mathrm{C}^{\prime} 4$ and of inhibitor of $\mathrm{C}^{\prime} 1$-esterase was then measured in each serum sample. The amount of $\mathrm{C}^{\prime} 4$ in the serum from a patient was already decreased, whereas that from the normal was not (Table III). This finding is consistent with the view that $C^{\prime} 1$-esterase acts upon $C^{\prime} 4$ in vivo in blood of persons with hereditary angioneurotic edema, rather than being an artifact resulting from in vitro generation of $\mathrm{C}^{\prime} 1$-esterase. The quantity of inhibitor was increased as predicted in the normal serum sample (Table III) and also increased in serum of the patients.

\section{Discussion}

Seven of twelve members of a kindred lacked measurable serum inhibitor of C'1-esterase (Figure 1). The presence of this abnormality in a person subject to characteristic attacks of swelling and pain favors the diagnosis of hereditary angioneurotic edema (8). Sera from over 500 other persons in health and disease have all contained inhibitor $(8,40)$. The incidence of this serum defect and of persons known to have attacks of edema in this kindred is consistent with the expression of an autosomal dominant trait. In this family, two children in generation VI (Figure 1) lacked inhibitor but have not yet had attacks of edema. In a family reported earlier, one of the children who lacked inhibitor has since begun to have episodes of localized swellings of the skin at 4 years of age. It is likely that the same fate awaits the children presently reported whose sera contain no inhibitor but who do not yet have symptoms.

TABLE III

$C^{\prime} 4$ in serum from blood drawn into purified serum inhibitor of C'1-esterase

\begin{tabular}{lccc}
\hline Serum & $\begin{array}{c}\text { Added } \\
\text { during } \\
\text { phlebotomy }\end{array}$ & $\begin{array}{c}\text { Measured } \\
\text { inhibitor } \\
\text { of C'l- } \\
\text { esterase }\end{array}$ & $C^{\prime} 4$ \\
\hline & & $\begin{array}{c}U / m l \\
\text { serum }\end{array}$ & $\begin{array}{c}U / m l \\
\text { serum }\end{array}$ \\
F.S.R. (normal) & 0 & 5.7 & 640 \\
F.S.R. (normal) & Inhibitor* & 11 & 480 \\
E.S. (patient) & 0 & 0 & 120 \\
E.S. (patient) & Inhibitor* & 9.5 & 80 \\
H.A.S. (patient) & 0 & 0 & 160 \\
H.A.S. (patient) & Inhibitor* & 7.1 & 120 \\
& & & \\
\hline
\end{tabular}

* $20 \%$ dilution of serum by added inhibitor. 
Serum and plasma from members of family $\mathrm{S}$ (Figure 1) who lacked serum inhibitor of $C^{\prime} 1$ esterase hydrolyzed $N$-acetyl-L-tyrosine ethyl ester, which is digested by $\mathrm{C}^{\prime} 1$-esterase but not by thrombin or plasmin, other hydrolytic enzymes sometimes found in serum and plasma. Purified human serum inhibitor of $C^{\prime} 1$-esterase blocked this esterolytic property in serum (Table I). In addition, the fourth $\left(C^{\prime} 4\right)$ and the second $\left(C^{\prime} 2\right)$ components of complement, both of which are inactivated in appropriate solutions by $\mathrm{C}^{\prime} 1$-esterase, were decreased or absent in sera having this enzymatic activity. Doubtless, the esterase activity in serum and plasma obtained between attacks was largely generated in vitro during assay (Figure 2), for both $\mathrm{C}^{\prime} 4$ and $\mathrm{C}^{\prime} 2$ were detectable in such serum samples. Therefore, in the absence of the serum inhibitor there is a tendency to enhanced generation of $C^{\prime} 1$-esterase in the blood of persons with hereditary angioneurotic edema. Blood drawn from a patient free of swelling into purified serum inhibitor of $C^{\prime} 1$-esterase already had decreased quantities of $\mathrm{C}^{\prime} 4$, indicating that small amounts of $\mathrm{C}^{\prime} 1$-esterase had acted in vivo.

The increased amounts of $\mathrm{C}^{\prime} 1$-esterase activity in serum and plasma of patients having attacks of swelling or pain suggested that $C^{\prime} 1$-esterase might have caused increased vascular permeability in susceptible areas of the body of a person with hereditary angioneurotic edema. Purified C'1esterase can effectively increase vascular permeability in the skin of the guinea pig, and purified inhibitor can block this response in a predictable fashion (10). Landerman, Webster, Becker, and Ratcliffe also reported that autologous intracutaneous injections of diluted serum from a patient with hereditary angioneurotic edema induced marked wheal formation, in contrast to similar injections of diluted normal serum (41). It is not clear how $\mathrm{C}^{\prime} 1$-esterase may increase vascular permeability. A subsequent biochemical event in the series initiated by activation of $C^{\prime} 1$ may be responsible. Since $C^{\prime} 3$ is apparently not altered in hereditary angioneurotic edema, the interactions between $C^{\prime} 1$-esterase and $C^{\prime} 4$ and $C^{\prime} 2$ may generate a factor that increases vascular permeability.

Evidently only a small portion of $\mathrm{C}^{\prime} 1$ is converted to $\mathrm{C}^{\prime} 1$-esterase in persons with hereditary angioneurotic edema who are not having attacks. There may be normal or slightly decreased quantities of hemolytic $C^{\prime} 1$ in their serum (Table II). Even so, amounts of $C^{\prime} 4$ and $C^{\prime} 2$ measured in similar assays were significantly reduced, reflecting the susceptibility of these components to inactivation by $\mathrm{C}^{\prime} 1$-esterase. One unit of $\mathrm{C}^{\prime} 1$-esterase can inactivate over $12,000 \mathrm{U}$ of $\mathrm{C}^{\prime} 4$ and $120 \mathrm{U}$ of $\mathrm{C}^{\prime} 2$, according to in vitro observations of Haines and Lepow (34).

A possibility to be considered was that $C^{\prime} 1$-esterase in serum of a patient could have resided in a low molecular weight fraction, in contrast to the localization of $C^{\prime} 1 \mathrm{~s}$ (proesterase) in high molecular weight fractions of normal serum. In patients' serum, however, active $C^{\prime} 1$-esterase was in fractions of higher molecular weight after ultracentrifugation in a sucrose density gradient. In addition, subcomponents of $C^{\prime} 1$ ( $C^{\prime} 1 q, C^{\prime} 1 r$, and $C^{\prime} 1 \mathrm{~s}$ ) were in fractions of similar molecular weights in plasma from a patient and from a normal person, and in serum from a patient and a normal person. These experiments did not differentiate the subcomponents of $C^{\prime} 1$ in hereditary angioneurotic edema from normal; enzymatically active $C^{\prime} 1$ ( $C^{\prime} 1$-esterase) was located in fractions known to contain $C^{\prime} 1$ s activity normally. Evidently $C^{\prime} 1$ activation did not require that the molecule be dissociated.

Müller-Eberhard, Nilsson, and Aronsson described a $\beta_{1 \mathrm{C}}$ globulin in fresh serum that can be substituted for guinea pig $C^{\prime} 3$ activity in a reagent markedly deficient in this component $(39,42)$. The human $\beta_{1 \mathrm{C}}$ represents a portion of human $C^{\prime} 3$ (37). During complement fixation, the electrophoretic mobility of antigenic $\beta_{1 \mathrm{c}}$ globulin in fresh serum was altered to that of a $\beta_{1 \mathrm{~A}}$ globulin (42). This alteration was evidently related to the participation of $C^{\prime} 3$ in the interactions of complement with antigen-antibody aggregates. Additional studies of Müller-Eberhard and Biro have identified a $\beta_{1 \mathrm{E}}$ globulin of human serum with $\mathrm{C}^{\prime} 4$ (36).

Titers of $C^{\prime} 4$ and $C^{\prime} 2$ were always decreased in serum from patients with hereditary angioneurotic edema, and immunoelectrophoretic patterns demonstrated altered $\beta_{1 \mathrm{E}}$ precipitin bands in hereditary angioneurotic edema and complement fixed serum, indicating changes in $\mathrm{C}^{\prime} 4$ in both 
situations (Figure 3). Titers of $C^{\prime} 3$ in patients' sera did not vary from those in normal sera, and the shift of antigenic $\beta_{1 \mathrm{C}}$ globulin to a $\beta_{1 \mathrm{~A}}$ position observed in complement fixed serum was absent in normal and hereditary angioneurotic edemá sera (Figure 3). Therefore, the changes in $\mathrm{C}^{\prime} 3$ occurring during complement fixation were not present in hereditary angioneurotic edema.

C'1-esterase may be one of several factors in human serum able to increase vascular permeability. Landerman and associates (41) reported that a patient with hereditary angioneurotic edema had decreased amounts of serum inhibitor of kallikrein, a serum enzyme capable of increasing vascular permeability by initiating the release of plasma kinins (43-48). They suggested that kallikrein might initiate edema formation in hereditary angioneurotic edema. Later, Kagan and Becker (49) reported that purified serum inhibitor of C'1-esterase impaired the action of a preparation of human plasma kallikrein and of PF/DIL, another permeability factor of serum (50). These reports suggested a relationship between these permeability factors and the complement system. However, C'1-esterase must not be identical with kallikrein or PF/DIL. C'1-esterase hydrolyzed $N$-acetyl-L-tyrosine ethyl ester (12), whereas preparations of plasma kallikrein did not (51). Moreover, C'1-esterase was not inhibited by soy bean trypsin inhibitor (15), but the plasma kallikrein and PF/DIL were $(50,51)$. Ultracentrifuge experiments tend to identify enzymatic activity in serum of patients with hereditary angioneurotic edema with $C^{\prime} 1 s$, the proesterase found in normal serum.

The events leading to enhanced generation of $\mathrm{C}^{\prime} 1$-esterase in blood of these patients are still undefined. Situations presenting a patient with emotional or physical trauma may precede an attack (8), and psychiatric studies of some of the members of the kindred presently described have been published (9). Although activation of $C^{\prime} 1$ in vitro can be readily accomplished upon contact with antigen-antibody aggregates, evidence that such an immune mechanism plays a role in inducing attacks of hereditary angioneurotic edema is unconvincing $(7,8)$. Possibly, the fibrinolytic protease, plasmin, becomes active during stress and in turn activates $\mathrm{C}^{\prime} 1$-esterase, as suggested earlier (8). Plasmin can activate $C^{\prime} 1$ proesterase under suitable in vitro conditions (15); anxiety, exercise, and injections of adrenaline can enhance the fibrinolytic activity of the blood in vivo, presumably by inducing the formation of plasmin $(52,53)$.

One of the most entrancing features of this disease remaining unexplained is the mechanism causing cessation of symptoms. Edema may subside rather suddenly, and the patient is well aware that his attack of swelling or pain is abruptly terminating. Attacks usually last 2 or 3 days and maintain their episodic nature. It is possible that tissue factors determine the end of swelling. Alternatively, mechanisms that enhance generation of C'1-esterase may cease to be effective, or a substrate required for continuation of enzymatic events may become exhausted.

\section{Summary}

Affected members of a kindred with hereditary angioneurotic edema lacked detectable serum inhibitor of C'1-esterase, which was present in a large group of other persons in health and disease. C'1-esterase activity found in their serum and plasma was markedly enhanced during attacks of angioneurotic edema but was not detectable in normal serum or plasma. Enhanced activation of $\mathrm{C}^{\prime} 1$-esterase was associated with increased vascular permeability characterizing attacks. In intervals between attacks of edema, hemolytic $\mathrm{C}^{\prime} 2$ and $\mathrm{C}^{\prime} 4$ were diminished; during attacks these activities were absent. $C^{\prime} 3$ levels remained normal in serum during and between attacks. Immunoelectrophoretic examination of sera also demonstrated that $\mathrm{C}^{\prime} 4$ was altered while $\mathrm{C}^{\prime} 3$ was unchanged.

Blood drawn from patients into highly purified serum inhibitor of $C^{\prime} 1$-esterase had diminished amounts of $C^{\prime} 4$. Therefore, C'1-esterase had apparently acted in vivo to reduce $\mathrm{C}^{\prime} 4$, and this reduction was not an in vitro artifact.

The macromolecular nature of $C^{\prime} 1$ in normal serum (32) was also demonstrable in hereditary angioneurotic edema serum. Enhanced C'1-esterase activity in the serum of patients was not accompanied by dissociation of the molecule. Enzymatic activity in hereditary angioneurotic edema 
serum and plasma was found in fractions that contained C'ls (proesterase) when normal serum was similarly fractionated.

\section{Acknowledgments}

It is a pleasure to acknowledge the assistance of others who made these studies possible. Dr. Jack Pensky and Mr. Goldwyn Hughes of the Institute of Pathology, Western Reserve University School of Medicine, Cleveland, Ohio, provided highly purified serum inhibitor of C'1-esterase; Dr. Franz Peetoom, with whom the immunoelectrophoretic experiments were performed, provided antiserum that formed precipitin reactions with both $\beta_{1 \mathrm{E}}$ and $\beta_{1 \mathrm{c}}$ globulins; Dr. Hans J. Müller-Eberhard, Scripps Clinic, La Jolla, Calif., generously provided antiserum that reacted with human $\beta_{1 \mathrm{E}}$ globulin. Dr. George B. Naff, Institute of Pathology, Western Reserve University, provided reagents to measure $C^{\prime} 1$ subcomponents and aided in conducting the experiments to separate and determine these entities; Mr. Earl Todd, also of the Institute of Pathology, prepared reagents for determining complement titers. Dr. Irwin Lepow generously provided the facilities for measuring the complement titers in his laboratory. Geraldine Nelson prepared the illustrations. The members of family $S$ have willingly participated in these studies; their continuing cooperation is appreciated. Dr. O. D. Ratnoff performed the permeability assay.

\section{References}

1. Osler, W., Sr. Hereditary angio-neurotic œdema. Amer. J. med. Sci. 1888, 95, 362.

2. Crowder, J. R., and T. R. Crowder. Five generations of angioneurotic edema. Arch. intern. Med. 1917, 20, 840.

3. Cockayne, E. A. Inherited Abnormalities of the Skin and Its Appendages. London, Oxford University Press, 1933, pp. 364-383.

4. Fineman, A. H. Hereditary angioneurotic edema. Ann. intern. Med. 1940, 14, 916.

5. Hagy, G. W., and I. Danhof. Genetic and physiological aspects of a family with chronic hereditary lymphedema (Nonne-Milroy Meige's disease) and hereditary angioneurotic edema. Amer. J. Human Genetics 1958, 10, 141.

6. Trigg, J. W. Hereditary angioneurotic edema. Report of a case with gastrointestinal manifestations. New Engl. J. Med. 1961, 264, 761.

7. Landerman, N. S. Hereditary angioneurotic edema, $\mathrm{I}$, case reports and review of the literature. J. Allergy 1962, 33, 316.

8. Donaldson, V. H., and R. R. Evans. A biochemical abnormality in hereditary angioneurotic edema. Absence of serum inhibitor of C'1-esterase. Amer. J. Med. 1963, 35, 37.

9. Heiner, D. C., and J. R. Blitzer. Familial paroxysmal dysfunction of the autonomic nervous system (a periodic disease), often precipitated by emotional stress. Pediatrics 1957, 20, 782.

10. Ratnoff, O. D., and I. H. Lepow. Complement as a mediator of inflammation. Enhancement of vascular permeability by purified human $\mathrm{C}^{\prime} 1$ esterase. J. exp. Med. 1963, 118, 681.

11. Pillemer, L., and E. E. Ecker. The terminology of the components of complement. Science 1941, 94, 437.

12. Lepow, I. H., O. D. Ratnoff, F. S. Rosen, and L. Pillemer. Observations on a pro-esterase associated with partially purified first component of human complement $\left(\mathrm{C}^{\prime} 1\right)$. Proc. Soc. exp. Biol. (N. Y.) 1956, 92, 32.

13. Lepow, I. H., O. D. Ratnoff, and L. Pillemer. Elution of an esterase from antigen-antibody aggregates treated with human complement. Proc. Soc. exp. Biol. (N. Y.) 1956, 92, 111.

14. Becker, E. L. Concerning the mechanism of complement action. II. The nature of the first component of guinea pig complement. J. Immunol. 1956, 77, 469.

15. Ratnoff, O. D., and I. H. Lepow. Some properties of an esterase derived from preparations of the first component of complement. J. exp. Med. 1957, 106, 327.

16. Lepow, I. H., O. D. Ratnoff, and L. R. Levy. Studies on the activation of a proesterase associated with partially purified first component of human complement. J. exp. Med. 1958, 107, 451.

17. Haines, A. L., and I. H. Lepow. Purification and properties of human C'l-esterase. Fed. Proc. 1962, $21,17$.

18. Haines, A. L., and I. H. Lepow. Studies on human C'1-esterase I. Purification and enzymatic properties. J. Immunol. 1964, 92, 456.

19. Lepow, I. H., G. B. Naff, E. W. Todd, J. Pensky, and C. F. Hinz, Jr., Chromatographic resolution of the first component of human complement into three activities. J. exp. Med. 1963, 117, 983.

20. Müller-Eberhard, H. J., and H. G. Kunkel. Isolation of a thermolabile serum protein which precipitates $\gamma$-globulin aggregates and participates in immune hemolysis. Proc. Soc. exp. Biol. (N. Y.) 1961, 106, 291.

21. Taranta, A., H. S. Weiss, and E. C. Franklin. Precipitating factor for aggregated $\gamma$-globulins in normal human sera. Nature (Lond.) 1961, 189, 239.

22. Haines, A. L., and I. H. Lepow. Studies on human C'1-esterase. III. Effect of rabbit anti-C'1-esterase on enzymatic and complement activities. J. Immunol. 1964, 92, 479.

23. Levy, L. R., and I. H. Lepow. Assay and properties of serum inhibitor of $C^{\prime}$ l-esterase. Proc. Soc. exp. Biol. (N. Y.) 1959, 101, 608.

24. Pensky, J., L. R. Levy, and I. H. Lepow.. Partial purification of a serum inhibitor of C'l-esterase. J. biol. Chem. 1961, 236, 1674. 
25. Pensky, J. Further purification of a human serum inhibitor of C'1-esterase. Fed. Proc. 1960, 19, 76.

26. Lepow, I. H., L. Wurz, O. D. Ratnoff, and L. Pillemer. Studies on the mechanism of inactivation of human complement by plasmin and by antigenantibody aggregates. I. The requirement for a factor resembling $\mathrm{C}^{\prime} 1$ and the role of $\mathrm{Ca}^{++}$. J. Immunol. 1954, 73, 146.

27. Bier, O. G., G. Leyton, M. M. Mayer, and M. Heidelberger. A comparison of human and guinea pig complements and their component fractions. J. exp. Med. 1945, 81, 449.

28. Kabat, E. A., and M. M. Mayer. Experimental Immunochemistry. Springfield, Ill., Charles C Thomas, 1948.

29. Lepow, I. H., and L. Pillemer. Studies on the mechanism of inactivation of human complement by plasmin and by antigen-antibody aggregates. II. Demonstration of two distinct reaction stages in complement fixation. J. Immunol. 1955, 75, 63.

30. Leon, M. A. Quantitative studies on the properdincomplement system. J. exp. Med. 1956, 103, 285.

31. Kent, J. F., A. G. Otero, and R. E. Harrigan. Relative specificity of serologic tests for syphilis in Mycobacterium leprae infection. Amer. J. clin. Path. 1957, 27, 539.

32. Naff, G. B., J. Pensky, and I. H. Lepow. The macromolecular nature of the first component of human complement. J. exp. Med. 1964, 119, 593.

33. Martin, R. G., and B. N. Ames. A method for determining the sedimentation behavior of enzymes; application to protein mixtures. J. biol. Chem. 1961, 236, 1372.

34. Haines, A. L., and I. H. Lepow. Studies on human C'l-esterase. II. Function of purified C'l-esterase in the human complement system. J. Immunol. 1964, 92, 468.

35. Grabar, P., and C. A. Williams. Méthode permettant l'étude conjuguée des propriétés électrophorétiques et immunochimiques d'un mélange de proteines; application au sérum sanguin. Biochim. biophys. Acta (Amst.) 1953, 10, 193.

36. Müller-Eberhard, H. J., and C. E. Biro. Isolation and description of the fourth component of human complement. J. exp. Med. 1963, 118, 447.

37. Rapp, H. J., and T. Borsos. Complement and hemolysis. Science 1963, 141, 738.

38. Peetoom, F. The Agar Precipitation Technique and Its Application as a Diagnostic and Analytical Method. Leiden, H. E. Stenfert Kroese N.V., 1963.

39. Müller-Eberhard, H. J., U. Nilsson, and T. Aronsson. Isolation and characterization of two $\beta_{1}-\mathrm{gly}-$ coproteins of human serum. J. exp. Med. 1960, 111, 201.

40. Donaldson, V. H. Unpublished observations.

41. Landerman, N. S., M. E. Webster, E. L. Becker, and H. E. Ratcliffe. Hereditary angioneurotic edema. II. Deficiency of inhibitor for serum globulin permeability factor and/or plasma kallikrein. J. Allergy 1962, 33, 330.

42. Müller-Eberhard, H. J., and U. Nilsson. Relation of a $\beta_{1}$-glycoprotein of human serum to the complement system. J. exp. Med. 1960, 111, 217.

43. Kraut, H., E. K. Frey, and E. Werle. Über den Nachweis und das Vorkommen des Kallikreins im Blut. Mitteilung uber Kallikrein. Hoppe-Seylers Z. physiol. Chem. 1933, 222, 73.

44. Holdstock, D. J., A. P. Mathias, and M. Schachter. A comparative study of kinin, kallidin, and bradykinin. Brit. J. Pharmacol. 1957, 12, 149.

45. Werle, E., W. Gotze, and A. Kepplee. Uber die Wirkung des Kallikreins auf den isolierten Darm und über ein neue darmkontrahierende Substanz. Biochem. Z. 1937, 289, 217.

46. Webster, M. E., and J. V. Pierce. The nature of the kallidins released from human plasma by kallikreins and other enzymes. Ann. N. Y. Acad. Sci. 1963, 104, 91.

47. Elliott, D. F., E. W. Horton, and G. P. Lewis. Action of pure bradykinin. J. Physiol. (Lond.) 1960, $153,473$.

48. Bhoola, K. D., J. D. Calle, and M. Schachter. The effect of bradykinin, serum kallikrein and other endogenous substances on capillary permeability in the guinea-pig. J. Physiol. (Lond.) 1960, 152, 75.

49. Kagan, L. J., and E. L. Becker. Inhibition of permeability globulins by $\mathrm{C}^{\prime}-1$ esterase inhibitor. Fed. Proc. 1963, 22, 613.

50. Miles, A. A., and D. C. Wilhelm. Enzyme-like globulins from serum reproducing the vascular phenomena of inflammation. I. An activable permeability factor and its inhibitor in guinea pig serum. Brit. J. exp. Path. 1955, 36, 71.

51. Webster, M. E., and J. V. Pierce. Action of the kallikreins on synthetic ester substrates. Proc. Soc. exp. Biol. (N. Y.) 1961, 107, 186.

52. MacFarlane, R. G., and R. Biggs. Observations of fibrinolysis. Spontaneous activity associated with surgery trauma, etc. Lancet 1946, 2, 862.

53. Biggs, R., R. G. MacFarlane, and J. Pilling. Observations on fibrinolysis. Experimental activity produced by exercise or adrenaline. Lancet 1947, 1,402 . 